\title{
Surya Namaskar Yoga as Talent Stimulation to Children's Dance Art
}

\author{
Putu Aditya Antara ${ }^{*}$ \\ ${ }^{1}$ Universitas Pendidikan Ganesha, Indonesia \\ *Corresponding author. Email: putuaditya.antara@undiksha.ac.id
}

\begin{abstract}
This study aims to find out 1) the habituation of Surya namaskar yoga activities as stimulation of children's dance talents; 2) factors related to Surya namaskar yoga activities as stimulation of children's dance talents. The research conducted at Bali Q-Ta Kindergarten in Keramas Village, Blahbatuh Subdistrict, Gianyar Regency, Bali, in 2014, consisting of 55 children. This research is qualitative research with an ethnographic approach. Data collection is done by conducting observations, interviews, and analysis of documents. Data analysis in this study uses qualitative data analysis techniques from Spradley, consisting of five analysis stages: domain analysis, taxonomy analysis, componential analysis, and theme analysis. The results showed 1) stimulation of children's dance talents developed by habituating Surya namaskar yoga when starting learning in the classroom through stages such as pranamasana, hasta uttanasana, on hastasana, aswa sancalanasana, parvatasana, astangga namaskara, bhujanggasana, prawatasana, aswa sancalasana, on hastasana, hasta uttanasana, pranamasana. 2) this study found several factors that support children developing dance talents, i.e. teachers knowing and understanding children's education, creating a pleasant learning atmosphere, establishing good communication and cooperation with parents, and supporting adequate learning facilities healthy environment.
\end{abstract}

Keywords: Child, Dance Art, Surya Namaskar Yoga

\section{INTRODUCTION}

Early education received in kindergarten is the foundation for further development. If the education and experience received are good, the child will have a strong foundation for forming a good personality following expectations. On the other hand, if the education and poor experience received by the child. Then, it can be imagined the future that the child will achieve. The importance of early education in kindergarten aims to form a strong foundation for children, demanding the presence of educators who are also competent in the field of children's education. Seeing the various things that need to be considered in the child's learning process, a teacher must understand every potential developed while making learning activities as attractive as possible for the child to do in the learning process.

Every child has a diversity of physically, psychically, intellectually, attitudes, interests, etc. It is a challenge that must be faced with all efforts and fortitude, and utmost patience. Especially in dance, there are often children who are not enthusiastic about making movements for dance development. The thing is challenging to handle by teachers who only have a short time in school. However, such problems need to be faced with patience and calmness while trying to find various solutions to overcome existing problems and obstacles.

The development of dance talents owned by children is indeed the duty of teachers in the school environment. Teachers in charge of developing children's dance arts should make every effort to motivate and invite children to participate in dance arts learning activities. It is intended so that the art of dance does not become a scourge that frightens and hates children. On the contrary, the development of dance talent should be a fun activity and, at the same time as a creative and recreational event for students. Therefore, this appreciation activity is a stimulus for children to love the richness of Indonesian cultural arts.

Bali province is consisting of 7 districts and one municipality. If it is explored more profoundly has a relatively different culture but, in general, has similarities. From the pilot project conducted in several kindergartens, researchers found a peculiarity that attracts researchers to research the development of 
children's dance talents. The research was found at Bali Q-Ta Kindergarten located in Keramas Village, Blahbatuh, Gianyar, Bali. During the preliminary observations at the kindergarten, researchers saw that the children who had only been there for a few months had shown progress on several things: children doing dance arts activities with passion and enthusiasm. It is reinforced again from the information provided by some teachers and parents of children that researchers encountered during the initial observations. At that time, some parents expressed their happiness at seeing a relatively rapid positive development in their children's dance talents. Based on researchers' preliminary observations, there is something typical in Bali Q-Ta Kindergarten, namely the development of children's dance talents done by practising Surya namaskar yoga at the beginning of learning. The statement is a point of urgency that researchers should explore more deeply about Surya namaskar yoga stimulation to develop children's dance talents in Bali Q-Ta Kindergarten.

\subsection{Research Scope}

This research focuses on "Surya namaskar yoga movement learning as a stimulation of the development of children's dance talents at Bali Q-Ta Kindergarten in Keramas Village, Blahbatuh, Gianyar, Bali".

\subsection{Research Problem}

1. How is Surya namaskar yoga learning in developing children's dance talents conducted by teachers at Bali Q-Ta Kindergarten in Keramas Village, Blahbatuh Subdistrict, Gianyar Regency, Bali?

2. What factors are related to children's dance talents developed through Surya namaskar yoga at Bali Q-Ta Kindergarten in Keramas Village, Blahbatuh Subdistrict, Gianyar Regency, Bali?

\subsection{Research Scope}

1. To know Surya namaskar yoga learning in developing children's dance talents performed by teachers at Bali Q-Ta Kindergarten in Keramas Village, Blahbatuh Subdistrict, Gianyar Regency, Bali.

2. To know the factors related to the development of children's dance talents developed through Surya namaskar yoga at Bali Q-Ta Kindergarten in Keramas Village, Blahbatuh Subdistrict, Gianyar Regency, Bali

\section{LITERATURE REVIEW}

\subsection{Children's Dance Talent}

Artistic talent is an exceptional talent that a person has. Guildford (in [1]) states that there are three dimensions contained in talent, namely: (1) Perceptual dimension, namely the ability to perform perceptions that include sensory sensitivity, attention, the orientation of space and time and speed of perception, (2) Psychomotor dimension, including strength, impulse, speed of motion, carefulness and coordination, and (3) Intellectual dimension, including memory, recognition, thinking and evaluative.

The development of artistic talent is certainly inherited through education carried out in both formal and informal education. It clearly stated that art knowledge is a conscious effort to bequeath or transmit art's ability to manifest cultural transformation from generation to generation conducted by artists or art actors to anyone called a prospective artist [2]. A child is a unique person who has different abilities and needs than an adult, and one of the specific needs of a child is the need to express themselves. Dance arts education can contribute to a child's personal development. The contribution in question relates to the provision of expression space, creative and imaginative potential, increased sensitivity of taste, fostering confidence, and cultural insights.

Dance art is a communicative art that uses motion as its material, but the action in dance is different from meaningful daily activity. The dance movement has been overhauled or moved from the pure and transformed into art [3]. Self-expression in the art of dance through elements of motion, space (shape and volume), time (rhythm), energy (dynamics). Implicit self-expression means communication because anyone expressing something has the purpose of conveying a message to others. The expression can also be interpreted as playing because play is a child's job that can provide freedom, fun, and challenge as when they play. Thus, expression in the art of dance means emotional learning that always involves creative power. It often appears spontaneously when the child performs movements to express something, communicate, and play.

Besides, Stinson translated the concept of dance art from Gardner's opinion by asserting that artistic talent is a way of thinking about art and structurally. Art talent consists of three parts: perception, production, and reflection [4]. Perception is the ability to see the differences in elements or an object's quality. The exhibition in question is the ability of a person to create art products. Reflection is the ability to see oneself by understanding others' work and choosing objects according to self-interest and not others. 
On the other hand, Laban stressed that dance learning in public schools (non-vocational) should emphasize creative dance learning to develop children's personalities. Creative dance learning is not oriented towards producing a performance of high artistic value, as created by a choreographer but moving according to his heart and giving joy to the child [5]. This statement is very reasonable because every child has a natural urge to perform movements such as 'dance'. Unconsciously, it is the best way to introduce dance early on in the child and allowed the child to develop the ability to express spontaneously through his movement (free dance).

The various theory explained above refers to a conclusion that the talent of dance art is an expression of feelings expressed by the human body's visual appearance and movement taking into account art structures such as perception, production, and reflection that are implemented with a sense of pleasure and joy.

\subsection{Surya Namaskar Yoga}

Yoga is a harmony between body and mind movements. The condition intended by yoga is sthiram sukham asanam which means that the situation is comfortable and steady [6]. Yoga is an entire health system that is beneficial for improving physical health, providing peace of mind, and peace of mind [7]. According to Worby [8], one of the yoga practitioners defines yoga as an ancient art and science form of Indian origin initially designed to strengthen and shape the body's attitude, calm, and concentrate the mind to enter into meditation.

One form of basic yoga is Surya namaskar yoga. Surya namaskar yoga is a form of yoga with the body's attitude to pay homage to the sun and feel the absorption of solar energy and penetrate our body system [9]. Saraswati asserts that Surya namaskar consists of 12 body attitudes as an essential technique in performing yoga. Such as Pranamasna (prayer position), Hasta Uttanasana (hand position raised), Padahastasana (bending to reach the feet), Assva Sancalanasana (riding position horse), Parvatasana (mountain position), Astanga Namaskara (prostration with eight limbs), Bhujangasana (snake position), Parvatasana (mountain position), Assva Sancalanasana (horseback riding position), Padahastasana (hand touching feet), Hasta Uttanasana (hand-raised position), and Pranamasana (prayer position) [9].

\section{RESEARCH METHODOLOGY}

The study used qualitative methods with a case study approach. Researchers focused on some restrictions on tracing to find meaningful deep interactions on developing children's dance talents using Surya namaskar yoga motion. In the data collection, the research process uses the "developmental research sequence" model: (1) determining the social situation of research, (2) carrying out participating observations, (3) making field notes, (4) carrying out descriptive observations, (5) conducting domain analysis, (6) conducting focused observations, (7) conducting taxonomic analysis, (8) carrying out selected observations, (9) conducting component analysis, (10) analyzing themes, (11) writing cultural themes, as well as (12) writing ethnography, thus referring to the data collection procedure put forward by Spradley [10]. The number of children who were the subject of the study amounted to 55 people in group A and group B in Bali Q-Ta Kindergarten. The children involved in this study were involved two teachers, one principal, five parents of children who were also informants to support all research data. Data analysis is carried out in an advanced and gradual manner by research after organizing the data. This research data analysis follows the Spradley model [10], which starts from step five. The types of analysis performed are as follows; domain analysis (step six), taxonomy analysis (step eight), componential analysis (step ten), and theme analysis (step eleven).

\section{RESULTS OF RESEARCH AND DISCUSSION}

\subsection{Surya Namaskar Yoga Learning Form for the Development of Children's Artistic Talents at Bali Q-Ta Kindergarten}

Based on the results of domain analysis, document analysis, and interviews with informants, teachers use various strategies to develop children's dance talents. One of the primary uses is the Surya namaskar yoga movement. The use of varied dance arts learning aims to make the child always happy and enjoy the learning activities such as starting learning activities with Surya namaskar yoga, understanding emotions, meditation, dancing and doing dolanan activities.

One example of an interview conducted with a teacher and domain analysis in the child's art talent development activities is as follows.

Principal: "There are several strategies that we do to develop children's dance talents, such as starting learning by doing Surya namaskar yoga. Also, we invite children to hold dolanan activities to familiarize children to express themselves through movement. One of our peculiarities compared to other kindergartens is always carrying out meditation in starting and ending learning activities."

In particular, this meditation and yoga activity is done to harmonize thoughts and deeds so that the child will be able to recognize emotions to express themselves and be more able to focus on following the learning. One of the ways is done in meditation is to regulate the inhale and exhale while listening to instrumental music. 
While children do yoga to develop children's dance talents, it is not yoga with complicated movements but basic and simple yoga such as Surya Namaskar Yoga. Surya namaskar is an essential technique in doing yoga. Flexibility and its applications help obtain a healthy, vital life and prepare for spiritual generation and raise awareness both mentally and movement. The stages of Surya namaskar movement such as Pranamasana (upright position and prayer), Hasta Uttanasana (hand raised), Padahastasana (bowing to hands at the feet), Asva Sancalanasana (horseback riding), Parvatasana (mountain position), Astanga Namaskara (prostration with eight body parts on the floor), Bhujangasana (snake position), Parvatasana (mountain position), Asva Sancalana (horseback riding position), Padahastanasana (hand touching feet), Hasta Uttanasana (hand-raising position), Pranamasana (upright position and praying). Therefore, familiarizing children with meditation and yoga will calm and recognize self-emotions to express themselves in dance movements. It becomes essential in the art of dance because only children who can feel happy and happy will naturally express themselves in dance movements.

Dance moves require good flexibility and contraction of the body, so it is very relevant if the learning begins with yoga movements. Sivasankaran affirms it in Peck [11], which revealed that yoga practice at least three times a week would lower blood pressure and heart rate because yoga makes blood vessels more flexible to contract better. Surya namaskar yoga lesson is done in a spacious room and has good air ventilation. Also, this activity is carried out in a space that allows sunlight to enter moderately so that the room is not too hot. This yoga activity is also done accompanied by instrumental music. Children's movements are tried not to force the child's body to move, but according to their ability.

Another study finds that data analysis can be conveyed that children's dance talents can be developed by combining the Surya namaskar yoga movement with creative movement. A combination of motion is used to express the inner experience and express one's feelings by giving the child the freedom to move according to his imagination by paying attention to time, space, and emphasis. Creative movements performed appropriately by children provide quality improvement and development in the physical, ability of balance and coordination, understanding of rhythm and tempo, and predicting future events and having a high body awareness.

\subsection{Factors related to the Development of Children's Dance Talents Developed Through the Surya Namaskar Yoga Movement at Bali Q-Ta Kindergarten}

Teachers are a significant factor. Teachers have adequate knowledge and understanding of the development of children's dance talents. Teachers are fully responsible for learning activities while the children are in kindergarten. Teachers' ability to establish communication and interact with children determines teachers' success in providing therapy. In addition to teachers, parents support the efforts made by teachers. Although when the children are in kindergarten, the teacher is the one who is fully responsible for the child. However, the parents' role is very influential in developing children's dance talents by using the Surya namaskar yoga movement. Parents' existence to comply with the school's various rules and continue the rules to be given at home helps them learn the Surya namaskar yoga movement given in school.

In addition to teachers and parents, the facilities and infrastructure factors also support developing children's dance talents. The learning facilities and facilities available at Bali Q-Ta Kindergarten are adequate. It can be seen both from the facilities. The classrooms' facilities are devoted to the learning of kindergarten children themselves and other rooms used together. This infrastructure's availability is beneficial for developing children's dance talents because teachers can use it to provide more varied stimulation programs to build children's dance talents that can be achieved more optimally.

Similarly, the Bali Q-Ta Kindergarten environment is also relatively healthy and healthy for implementing shopping activities. The room's clean condition and enough lighting make the child feel at home locally and can play and explore, developing their abilities. Also, the cool rural area and rice field atmosphere make the learning atmosphere calm. Similarly, the schoolyard's conditions and situations are always clean and tidy, keeping children away from threatening dangers.

\section{CONCLUSIONS AND SUGGESTIONS}

First, the concept of developing children's dance talents developed at Bali Q-Ta Kindergarten uses Surya namaskar yoga movement consisting of several movements such as Pranamasana (upright position and prayer), Hasta Uttanasana (raised hand), Padahastasana (bending to hand at foot), Asva Sancalanasana (horseback riding), Parvatasana (mountain position), Astanga Namaskara (prostration with eight body parts on the floor), Bhujangasana (snake position), Parvatasana (mountain position), Asva Sancalanasana (horseback riding position), Padahastanasana (hand touching feet), Hasta Uttanasana (hand-raising position), Pranamasana (upright position and praying). Surya namaskar yoga movement is done when the child will be given dance art learning. The child is also invited to do meditation to recognize self-emotions that will be expressed in body movements. The development of children's dance talents is also developed by combining Surya namaskar yoga motion with creative movement, which is a combination 
motion to express the inner experience and express someone's feelings and is done by giving the freedom to the child to move according to his imagination by paying attention to time, space and emphasis.

Second, factors related to children's dance talents such as teacher quality, cooperation with parents, and learning infrastructure facilities are available. Bali Q-Ta Kindergarten is adequate and supports Surya namaskar yoga's implementation to stimulate children's dance talents.

Teachers are expected to improve their competence in performing Surya namaskar yoga to develop dance talents to handle children's various characteristics. Also, teachers must always communicate with the child's parents to develop children's dance talents more holistic and sustainable. Kindergarten managers support teachers in building children's dance talents, especially allowing teachers to participate in special training and education to develop children's dance talents. At the same time, parents should show good cooperation with teachers by obeying the discipline and motivating them to comply with the discipline applied in kindergarten. Parents should also set an excellent example in communicating with children at home to quickly find a good person figure and become the role model. In this study, other researchers also suggested continuing this research on the model of development of children's dance art talents that can be used in various research sites so that suitable formulations are found to develop children's dance talents throughout Indonesia.

\section{REFERENCES}

[1] F. Muba, Bakat Khusus (http://febryanmuba.blogspot.com/2010/10, Accessed 10 Desember 2012.

[2] M. Jazuli, Telaah Teoretis Seni Tari, Semarang: IKIP Press, 1994.

[3] A. M. Hawkins, Bergerak Menurut Kata Hati. Metode Baru, in: Menciptakan Tari, diterjemahkan oleh I Wayan Dibia, Jakarta: Ford Foaundation dan Masyarakat Seni Indonesia, 2003.

[4] S. W. Stinson, Promising Practice in Arts Educations Assessment (Los Angeles: Proceeding of The International Early Childhood Creative Arts Conference-American Alliance for Health, Physical Educations, Recreation and Dance, 1991.

[5] R. Laban, Modern Educational Dance, New York: McDonald and Evans Ltd., 1976.

[6] S. Sivananda, Kundalini Yoga, Penjedar, Malang, 1969.

[7] F. Ranti, Shidma Yoga, Surabaya: Dunia Pustaka, 2011.
[8] C. Worby, Memahami Segalanya Tentang Yoga, Tangerang: Karisma, 2007

[9] S. S. Sarasvati, Asana Pranayama Mudra Bandha, Surabaya: Paramita, 2002.

[10] J. P. Spradley, Participant Observation, New York: Holt, Rinehart and Winston, 1980.

[11] P. Peck, Yoga Gets Hearts Healthy, WebMD Medical News [On-line] (2004), In: http://www.webmd.com. Download 17 Juli 2014. 